\title{
LEADERSHIP ELITISM - IDEALISM VS. REALISM
}

\begin{abstract}
Philosophies of leadership have tended to express and support idealistic or realistic approaches to leadership. Leadership elitism maintains essentially that successful leaders must know and do what is best for their followers, because their followers are not capable of knowing and doing what is best for themselves. This essay offers descriptions of the contrasting traits of leadership idealism and realism, both of which explain elitism as a common trait of idealism. These descriptions are exemplified with an overview of some past and current leadership philosophies, and then with an in-depth analysis of the early twentieth-century views of the African-Americans thinkers W.E.B. Du Bois (idealist) and Booker T. Washington (realist). Some remarks on where leadership philosophy is and could be in the twenty-first century conclude the essay.
\end{abstract}

Keywords: leadership philosophies, leadership idealism vs. realism, leadership in twenty-first century, Plato, Aristotle, Lao Tzu, Tolstoy, Thomas Carlyle, Machiavelli, Booker T. Washington, W.E.B. Du Bois, Thomas Wren

1. Nine Contrasting Tendencies of Idealist vs. Realist Leadership Philosophies. 2. Overview of Some Major Leadership Philosophies. 3. The Washington and Du Bois Opposition. 4. Concluding Remarks: Quo Vadis Leadership? Appendix: Leadership Elitism - Idealism vs. Realism.

If it is accepted that a measure of the merits of a civilization is the substance of its predominant philosophies, then a civilization's philosophies of leadership are essential to assessing its merits. Philosophies of leadership can contribute to orienting, driving and even largely defining the status and movement of a civilization. Leadership philosophies can turn a civilization toward oppressive totalitarianism or humane freedom; they can engender a democratic republic that values the individual person or a depersonalizing socio-economic collectivism led by elitist tyrants. It is crucial, then, to explicate and critique leadership philosophies to expose their tendencies and 
possible consequences when put into action. A valuable conceptual framework for this task is the dichotomy between elitist leadership idealism and leadership realism.

There are many types of elites, ranging from business to politics, media and even ethnic groups, religion, and education. What all of these types of elites have in common, as implied by the lexical definition of "elite," is the "social superiority" of a particular individual or group. "Elitism," however, has a more specific definition, namely, "leadership or rule by an elite." 2 By merging these meanings, "elitism" can be interpreted as a type of leadership in which leaders, within any sort of organization, are regarded, or conceive themselves, as superior. Superiority, whether accorded to leaders by members of an organization or merely assumed by the leaders themselves, is, then, a distinguishing trait of elitist leadership.

The history of the philosophy of leadership is extensive. During different historical eras, diverse philosophies of leadership emerged. A constant philosophical theme, however, can be identified throughout the various historical expressions of leadership philosophies. That theme is fundamental to philosophy itself and it is the opposition between idealism and realism, with its epistemological, psychological and political implications. Leadership philosophies, in general, can be understood as leaning toward the idealist or realist perspective, and elitism can be exposed as a trait of leadership idealism.

This essay describes leadership idealism as maintaining essentially that successful leaders in an organization of any scale must themselves know and do what is best for their followers, their subordinates. This is so because idealism typically considers leaders as superior, and the followers, the inferiors, as just not capable of knowing and doing what is best for themselves.

1 Webster's New Collegiate Dictionary, G. \& C. Merriam Co., Springfield, MA 1980, 366.

2 Ibidem. 
The exposition of leadership elitism begins with charting (see Appendix) the contrasting traits which characterize leadership idealism versus realism. An historical overview of significant idealist and realist leadership philosophies follows using the examples of Plato, Aristotle, Lao Tzu, Machiavelli, Thomas Carlyle, and Leo Tolstoy. Next, an in-depth examination focuses on the contrast between the early twentieth-century views of the African-American thinkers W.E.B. Du Bois (idealist) and Booker T. Washington (realist). The $\mathrm{Du}$ Bois/Washington dispute is detailed since it is especially relevant to the current state of leadership in the U.S.A. Brief remarks on the future of leadership conclude this essay.

\section{NINE CONTRASTING TENDENCIES OF IDEALIST VS. REALIST LEADERSHIP PHILOSOPHIES}

Before explaining nine contrasting traits of leadership idealism and realism, it is important to emphasize that such traits are not necessarily characteristic of every idealist or realist leadership philosophy. In other words, some traits may be characteristic of some idealist or realist approaches, and others may not. Moreover, a particular trait may be characteristic of a particular leader or philosophy to a greater or lesser degree. Finally, it is helpful to analyze leadership traits keeping in mind that idealist or realist philosophies tend to have at least some but not necessarily all of these traits. Hence, the title of this section indicates contrasting tendencies to highlight the tendentious status of the leadership traits.

Another important point to emphasize regarding the descriptions of these tendencies and the ensuing historical overview is that although they are intended as having a broad scope, they also have relevant application to particular leaders in organizations of almost any kind or size. The descriptions refer to leadership in general: any individual with leadership status in any organization can manifest the idealistic or realist tendencies in ways that are contextualized 
within that type of organization. The leadership philosophies selected principally focus on large-scale leadership. This would include leaders of nations, international organizations (such as the United Nations or the European Economic Union), military forces, religions, or revolutionary movements. On a smaller scale, however, the leadership philosophies could also apply to the likes of a university dean, a corporate department head, a trade union leader, or a parish priest. Any and all leaders who have subordinates, followers, can manifest idealistic or realistic tendencies depending upon their ways of conceiving their leadership status and enacting their leadership authority.

The first contrasting tendency within the idealist versus realist leadership framework reflects the most fundamental distinction between the two approaches. It also exposes the connection between idealism and elitism. For the idealist, leaders are born as such. The capacity for leadership is inherent or innate and, as such, it confirms that the leader has an in-born superiority, and is, thereby, gifted with an elite status. In contrast, realism believes that the ability to lead can be taught, and, thereby, acquired.

Leaders are not innately superior or part of an elite, but their leadership can be nurtured, learned and formed by proper training and education. They do not possess a superiority which is a function of an inherent elite status, but gain authority through implementing responsibly the best practices they have learned through training and education to achieve what is best for their followers and the organization itself.

In line with the first tendency, idealist leaders view their leadership as a type of destiny fulfillment: they are born to lead; they have been chosen or anointed; they are the "elect." Darwinian natural selection, divine ordination, or inherited birthright are just some of the reasons for affirming their leadership superiority as a "given" to which they are entitled. Realists, on the other hand, believe that leadership is earned. When they earn the responsibility to lead others, they know 
that their continued status as a leader depends on their success with their followers: i.e., how well they can motivate and guide their followers to contribute beneficially to the good of the organization.

Idealist leaders are thoroughgoing visionaries. They are dedicated to a vision of perfection as they conceive it, a utopian ideal for the organization. On the contrary, realists form their visions in terms of concrete, practicable goals. They are not animated by some "piein-the-sky" dream. They have down-to-earth, creative imagination and aim to translate practicable intentions into the reality of their organization in concert with the cooperation of their followers. ${ }^{3}$

Just as epistemological idealists believe that reality is what conforms to their mind, idealist leaders aim to make or re-make an organization conform to their vision. In doing so, they intend to implement their own organizational reality. Realists, on the contrary, appreciate that feasibility requires that goals must conform to the existing reality of an organization, which would include the mission, purpose and resources of the organization and of their followers. They lead, therefore, within the given parameters of the realities of an organization. They are aware that a leader's unrealistic intention does not translate into, but actually undermines, the reality of an organization.

There is an ethical relativism within idealistic leadership in that such leaders typically exercise situational ethics and make moral judgements according to what they deem to be right in a situation. In so doing, they invent, in fact, their own ethical standards as to what will best serve their interests and their vision. Realistic leaders eschew such situationalism and aim to discover the best and right ethical standards they can apply in different types of situations. This is not situation ethics, but ethics in the situation.

Idealistic leaders tend to be self-centered. For them, an organization ought to be a projection of themselves, of their own egos which

3 W. Bennis, The Artform of Leadership (1982), in: The Leader's Companion, ed. by J. Th. Wren, Simon and Schuster Inc., New York 1995, 377. 
spawned their ideal vision. Consequently, they are typically intolerant of opposition and interpret criticism and disagreement about what is best for their organization as personal assaults that must be eliminated. Realists, in contrast, accept that an organization is greater than any egotistical projection; hence, their leadership is not about them personally. Rather, it is about an organization's mission and their followers. They dispose themselves to their organization, leading with humility and charity.

Hope and change are the usual message of idealistic leaders. For them, however, the message is egocentric since hope aims to actualize the utopian vision the leaders concoct. Change strives to transform an organization's reality through any means, to make it conform to that which the leader hopes. Realistic hope and change transmit a much different message. Hope adheres to an organization's reality in the conviction that conforming to the best and right standards will engender what is truly good for the organization. Change strives to actualize the best and right standards within an organization's reality.

Because the ideal supplants the real for idealist leaders, they tend to ignore or de-emphasize the possible consequences of their visionary ideas for changing an organization. Since their ideas of such change are per se the best for instantiating their vision, whether those ideas will actually work is a detail they dismiss. Such leaders maintain that 'of course their ideas will work because their ideas are extensions of their own egocentric vision.' Unlike idealists, realist leaders know that ideas have real consequences that must be foreseen to the best of one's ability and factored into assessing whether an idea would indeed be feasible and benefit the organization.

The final contrasting tendencies pertain to the ways in which leaders view their subordinates. Elitist idealists tend to reify their subordinates as collective entities because in doing so, they are able to assign their own "identities" to their followers. For example, such leaders might tend to view subordinates principally according 
to race/ethnicity so that they define themselves as leading AfricanAmericans, Hispanics, Asians etc., who can be divided into further groups like men/woman/LGBTQ types. This collectivism is truly an idealistic tendency for it enables the leader to fabricate a diverse individuality of the followers according to the leader's projected group traits: the real, individual identities of the followers are subsumed into the collective group identity the leader concocts. Realist leaders, on the contrary, tend to strive to get to know, respect, and treat individual followers for who they are and not as mere instances of the collective identity the leader has projected upon them.

These contrasting tendencies of realist and idealist leadership are, as indicated above, apparent with leaders in all sorts of organizations. It can easily be seen that idealist leadership is a bane to organizations, and, of course, the larger the organization and the more powerful the leader, the greater those people within the organization will suffer the misguidance of the leader's unreal elitist vision. As it happens, the most important leadership philosophies have indeed advanced idealistic leadership.

\section{OVERVIEW OF SOME MAJOR LEADERSHIP PHILOSOPHIES}

The prototypical idealist and realist are, of course, Plato and Aristotle. They establish the fundamental differences between idealist and realist leadership. Plato's elitist approach denigrates the "insatiable desire" 4 for freedom within democracy, which spawns rampant equality thus yielding anarchy and ultimately tyranny. The alternative to such an inferior government is the leadership of the naturally superior "philosopher king," who is born to lead. As Plato indicates, "There will be discovered to be some natures who ought to study

4 Plato, The Republic, VIII, 562d., The Republic, in: The Leader's Companion, op. cit., 60. Excerpted from: The Republic of Plato: An Ideal Commonwealth, trans. B. Jowett, rev. ed. Colonial Press, New York 1901. 
philosophy and to be leaders in the State; and others who are not born to be philosophers, and are meant to be followers rather than leaders." 5 Aristotle's realism rejects Plato's elitist leadership, asserting that "Kings have no marked superiority over their subjects."' Also, leaders do not have an in-born entitlement to leadership because, for Aristotle, "all citizens alike should take their turn of governing and being governed." $\mathrm{He}$ affirms that democratic equality is necessary for maintaining the ethical principle of justice in leadership, government and society. He further denounces egotistical leadership by claiming that leaders ought to have the humility to understand and orient themselves to the realities of their followers. This perspective, which is at the very core of his leadership realism, is expressed by his notable maxim that, "he who would learn to command must (...) first of all learn to obey."

As was to be expected, the realism of the Ancient Chinese philosopher Lao Tzu was not influential on Western leadership. It was not significantly influential on Eastern leadership either, as the twentieth-century idealist personality cult of the revolutionary Chairman Mao demonstrates. Lao Tzu's philosophy, nevertheless, offers a worthwhile exemplification of realist leadership. The predominant theme in his philosophy is a warning against egotistical leadership. He stresses that "Enlightened leadership is service, not selfishness. The leader grows more and lasts longer by placing the well-being of all above the well-being of self alone." Selfish leaders impose an unreal, idealistic vision on the followers.

5 Ibidem, V, 474c., 63.

6 Aristotle, Politics, VII.14, 1332b24, trans. W. Ellis. Aristotle, Politics, in: The Leader's Companion, op. cit., 65. Excerpted from: Aristotle, A Treatise on Government, trans. W. Ellis, ed. by E. Rhys, J.M. Dent \& Sons, London 1941, 226.

7 Ibidem, VII.14, 1332b 26-27, in: The Leader's Companion, op. cit., 65.

8 Ibidem, Pol. VII.14, 1333a 1-2, in: The Leader's Companion, op. cit., 66.

9 Lao Tzu, Tao Te Ching, Chapter 7, Selflessness, in: The Leader's Companion, 69. Excerpted from: J. Heider, The Tao of Leadership, Humanics Limited, Atlanta, GA 1985, 13. 
For Lao Tzu, instead, leaders should be "unbiased, clear and downto-earth." 10 They should not "intervene unnecessarily"11 and should not require their followers to trust them. Rather, by trusting their followers, leaders will gain their followers' trust. Wise leaders should also deal with what is really happening within an organization, rather than what they "think ought to be happening." ${ }^{2}$ Lao Tzu's leadership philosophy certainly exemplifies the other-oriented humility of realist leadership, which assesses whether leaders are good on the basis of their success with their followers for the benefit of an organization.

If one considers Machiavelli's The Prince as a model of "Realpolitik," it will seem strange to classify his leadership philosophy as idealist. It does, however, have a number of idealist tendencies which qualify it as a form of idealism, or more specifically, a pragmatic idealism. The idealism is manifest with Machiavelli's beliefs that the Prince is an egotistical elite whose subjects are mostly "the vulgar," ${ }^{13}$ and that the Prince should use any means necessary to win and maintain his individual power in order to implement his agenda, his vision. Deceit is effective because the vulgar are typically "willing dupes," and since they often act like "beasts," 14 force is at times necessary. As Machiavelli advises, the Prince "should know how to follow evil courses if he must." 15 Such an 'end justifies the means' sort of pragmatism advances the moral relativism of situation ethics, especially since the end is invariably the Prince's selfish drive for

10 Lao Tzu, Tao Te Ching, Chapter 10, Unbiased Leadership, in: The Leader's Companion, op. cit., 71. J. Heider, The Tao of Leadership, op. cit., 19.

11 Lao Tzu, Tao Te Ching, Chapter 17, Being a Midwife, in: The Leader's Companion, op. cit., 70. J. Heider, The Tao of Leadership, op. cit., 33.

12 Lao Tzu, Tao Te Ching, Chapter 17, in: The Leader's Companion, op. cit., 71. J. Heider, The Tao of Leadership, op. cit., 33.

13 N. Machiavelli, The Prince, Chapter XVIII, How Princes Should Keep Faith, in: The Leader's Companion, op. cit., 68. Excerpted from: The Prince, trans. N.H. Thompson, Limited Editions, New York 1954.

14 Ibidem, 67.

15 Ibidem, 68. 
power. Beyond the Prince's aim to secure his power and vision, there are no genuine ethical principles which are applied to situations. The Prince simply invents his own ethics, for "if he succeeds in establishing and maintaining his authority, the means will always be judged honorable." ${ }^{16}$

The Modern idealism of Thomas Carlyle and Leo Tolstoy starkly exemplify some of the most basic tendencies of idealistic leadership. Like Plato's "philosopher king," Carlyle believes that the best leader is the "Ableman," one who is born to lead, an elite who should "command over us" and "tell us for the day and hour what we are to do." ${ }^{17}$ The Ableman is superior to all of the protocols and processes of government and ought to be given the authority to lead as he so desires because his leadership will create a utopia. Carlyle is uninhibited in his exaltation of the Ableman: "Find in a country the Ablest Man that exists there; raise him to the supreme place, and loyally reverence him: you have a perfect government for that country; no ballot box, parliamentary eloquence, voting, constitutionbuilding, or other machinery can improve it a whit. It is the perfect state; an ideal country." 18

Tolstoy's beliefs are even more radically idealist than Carlyle's. Whereas Plato identified the "insatiable desire" for freedom in democracy as a cause of tyranny, Tolstoy advances a type of idealist metaphysics that essentially denies freedom. He contends that all men, and especially leaders, are moved by the inexorable course of history. For Tolstoy, a leader is, in fact, "history's slave."19 "Man

16 Ibidem, 68.

17 Th. Carlyle, On Heroes, Hero Worship, and the Heroic in History, Lecture VI, The Hero as King, in: The Leader's Companion, op. cit, 53. Excerpted from: Th. Carlyle, On Heroes, Hero Worship, and the Heroic in History, Ginn and Co., New York 1902, 223.

18 Ibidem, 54.

19 L. Tolstoy, Rulers and Generals Are History's Slaves, in: The Leader's Companion, op. cit., 58. Excerpted from: L. Tolstoy, War and Peace, Book Three, Part One, Oxford Univ. Press, New York 1903, 649. 
lives consciously for himself, but is an unconscious instrument in the attainment of the historic, universal, aims of humanity. The higher a man stands on the social ladder, the more people he is connected with and the more power he has over others, the more evident is the predestination and inevitability of his every action."20

The actions of leaders and their followers are predetermined. "Every act of theirs, which appears to them an act of their own will, is, in an historical sense, involuntary and is related to the whole course of history and is predestined from eternity." 21 There are no real choices, no real achievements, no authentic individual responsibility or accountability. Tolstoy's idealism erases any sort of leadership that can be learned, earned and ethically enacted. Tolstoy's leaders can take no credit, but, at the same time, are absolved from any blame for their actions, because whatever they do is not in their control. They are merely subject to the movements of history. Such idealist leaders can, of course, be most dangerous as the twentieth-century Communist revolutions in Tolstoy's 'Mother Russia' graphically demonstrated.

\section{THE WASHINGTON AND DU BOIS OPPOSITION}

The opposition between the idealist W.E.B. Du Bois and the realist Booker T. Washington offers a profound study in the contrasts not only between leadership philosophies, but also within actual leadership behavior. Both men were fully engaged in implementing their philosophies, and both are extremely important for understanding the historical development of African-American advancement in the USA. Their contrasting beliefs and accomplishments are indeed most relevant even today as African-Americans continue to seek leaders and a leadership philosophy which will successfully overcome

20 L. Tolstoy, War and Peace, op. cit., 649. The Leader's Companion, op. cit., 58.

21 L. Tolstoy, War and Peace, op. cit., 649. The Leader's Companion, op. cit., 59. 
the racial, socio-economic, governmental, and cultural barriers which impede their advancement.

Washington was born into slavery and grew up in poverty. Having received some literacy instruction from the wife of a coal mine owner for whom his father worked, and being strongly encouraged to improve his literacy skills by his illiterate mother, Washington moved from Malden, West Virginia to Hampton, Virginia where he was admitted to the Hampton Institute. This Institute was founded after the Civil War to educate freed slaves in academic subjects and in the industrial arts. Washington went on to found the Tuskegee Institute in Alabama, which supplemented academic courses with occupational training and still exists to this day. Over time, he became a nationally prominent educator and leader, opening teachers colleges, receiving substantial funding from wealthy businessmen, and was the first African-American invited to the White House, where he consulted and dined with President Theodore Roosevelt in 1901. His autobiography Up from Slavery (1901) was a bestseller and remains an American classic. It has served to inspire the commercial, agricultural, educational and industrial advancement of AfricanAmericans. ${ }^{22}$ The inscription at the base of the Booker T. Washington monument at the center of Tuskegee University campus sums up his purpose: "He lifted the veil of ignorance from his people and pointed the way to progress through education and industry."23

Du Bois, 12 years younger than Washington, grew up in an entirely different milieu in the more urban Massachusetts. Raised by a single mother, he did not enjoy prosperity. Due to his scholastic success, however, he received funding to attend Fisk University in Tennessee. $\mathrm{He}$ subsequently earned a Ph.D. from Harvard and received

22 Biographical data for Booker T. Washington are largely based on: J.H. Franklin, Three Negro Classics, Introduction, Avon Books, New York 1965, 7-21.

23 The "Lifting the Veil" statue at Tuskegee Institute is a USA National Historic Site and the inscription on it is well known. https://atlantaplanit.wabe.org/attractions/booker-t-washington-lifting-the-veil-of-ignorance/ [accessed on 29 January 2019]. 
a fellowship to study at the University of Berlin. He travelled widely in Europe, Russia, China, Japan and Africa. Du Bois consistently applied his classical education, writing skills, teaching experience, and social activism to the benefit of African-American causes. $\mathrm{He}$ was an organizer and co-founder in 1909 of the National Association for the Advancement of Colored People (NAACP) and the founding editor of The Crisis, the official magazine of the NAACP. His political activism in the early twentieth-century Progressive Era ultimately led him to embrace Communism and become a staunch supporter of Joseph Stalin ${ }^{24}$ and Chairman Mao. He died at the age of 95 in Ghana, where he had become a citizen after having been refused a US passport to travel there to direct the development of The Encyclopedia Africana ${ }^{25} \mathrm{His}$ prolific writings, broad accomplishments, and activist legacy influenced generations of African-American leaders, and continue to do so today. Speaking at an event marking the hundredth anniversary of Du Bois' birth, Martin Luther King said: "We cannot talk of Du Bois without recognizing that he was a radical all his life. Some people would like to ignore the fact that he was a Communist in his later years. It is time [however] to cease muting the fact that $\mathrm{Du}$ Bois was a genius and chose to be a Communist. Dr. Du Bois'

24 Du Bois expressed admiration for Stalin and the Soviet Union throughout his writings. Upon the death of Joseph Stalin, he wrote, "Joseph Stalin was a great man; few other men of the 20c approach his stature. He seldom lost his poise; pondered his problems slowly; made his decisions clearly and firmly; [he never] coyly refrained from holding his rightful place with dignity; he knew the common man, felt his problems, followed his fate." W.E. B. DuBois, On Stalin, National Guardian (1953) 16, March. http://www.hartford-hwp.com/archives/45a/700.html [accessed on 29 January 2019]. DuBois, unlike most American Progressives, dismissed reports of Stalin's purges. Wilson Moses believes that Dubois idealized 'strong man' leaders, like Stalin, Mao, and Kwame Nkrumah (Ghana), and was accepting of their dictatorial brutality. Cf., W.T. Moses, Culture, Civilization and the Decline of the West, in: W.E.B. on Race and Culture, ed. by B. Bell, E. Gosholz, J. Stewart, Routledge, New York 2013, 243-260.

25 Biographical data for W.E.B. DuBois are largely based on: J.H. Franklin, Three Negro Classics, op. cit., 7-21. 
greatest virtue was his committed empathy with all the oppressed and his divine dissatisfaction with all forms of injustice."26

$\mathrm{Du}$ Bois' idealism extended throughout his career, in both his writings and activist organizational leadership. He held that a "Talented Tenth" elite of "exceptional men" should lead and save the "Negro race," as they will rise and pull "all that are worth saving up to their vantage ground." ${ }^{27} \mathrm{He}$ expressed a high degree of utopian zeal for the salvific possibilities of the Talented Tenth, whose "knowledge of modern culture would guide the American Negro into a higher civilization." 28 This idealistic vision was even more expansive, since he believed that the Talented Tenth offered a chance for: "young women and men of devotion to lift again the banner of humanity and to walk toward a civilization which will be free and intelligent, which will be healthy and unafraid and build in the world a culture led by black folk and joined by people of all colors and all races - without poverty, ignorance and disease." 29

Du Bois' elitist vision led him to manifest other idealist tendencies, such as the egotism of his claim that "I am the one who tells the truth and exposes evil and seeks Beauty for beauty to set the world right." 30

26 Martin Luther King, Speech Honoring Dr. DuBois, delivered at Carnegie Hall, New York City, February 23, 1968, http://www.ushistory.org/documents/dubois.htm [accessed on 30 January 2019].

27 W.E.B. DuBois, The Talented Tenth, in: The Leader's Companion, op. cit., 79. Excerpted from: W.E.B. DuBois, The Talented Tenth, in: The Negro Problem, James Pott \& Co., New York 1903, 33, 45; https://archive.org/stream/negroproblemseri00washrich/negroproblemseri00washrich_djvu [accessed on 30 January 2019].

28 W.E.B. DuBois, The Autobiography of W.E.B. DuBois, International Publishers, Inc., New York, NY 1968, quoted in: F. Nevin, The Contributions of Booker T. Washington and W.E.B. Du Bois in the Development of Vocational Education, Journal of Industrial Teacher Education 34(1997)4, 90.

29 The Negro Problem, op. cit., 74-75.

30 W.E.B. DuBois, Introduction, in: The Wisdom of W.E.B. Dubois, ed. by Aberjhani, Kensington Publishing Corp., New York 2003, xi. 
He expressed harsh scorn for the "headless misguided rabble" 31 of common African-Americans. In an essay on birth control published in Margaret Sanger's Birth Control Review, he warned that "[t]he mass of ignorant Negroes still breed carelessly and disastrously, so that the increase among Negroes, even more than the increase among whites, is from that part of the population least intelligent and fit, and least able to rear their children properly." 32 Finally, he also conveyed a definite animus for those who he believed opposed him, dismissing editors of Negro newspapers who dared criticize his views as "croaking toads," and insisting that "the most ordinary Negro is a distinct gentleman, but it takes extraordinary training and opportunity to make the average white man anything but a hog." 33

Progressive idealists, such as Du Bois, criticized Washington's philosophy and accomplishments as accommodating the interests of Whites. Washington, however, remained undeterred. He was a self-made man, firmly dedicated to the proposition that good character, good work and selfless service to others will earn respect and prosperity. He stressed that "[c]haracter is a power." 34 "Character, not circumstances, makes the man." 35 "You may fill

31 W.E.B. DuBois, The Talented Tenth, in: The Leader's Companion, op. cit., 80; in: The Negro Problem, op. cit., 62.

32 W.E.B. DuBois, Negroes and Birth Control, in: The Birth Control Review, ed. by M. Sanger, reprint 1939, Smith Libraries Exhibits, https://libex.smith.edu/omeka/items/show/491 [accessed on 30 January 2019].

33 R. McGill, W.E.B. DuBois, The Atlantic Monthly, (1965)11, 38, 37. This is an interview, including a commentary, with DuBois. https://www.theatlantic.com/past/docs/unbound/ flashbks/black/mcgillbh.htm [accessed on 30 January 2019].

34 B.T. Washington, Character Building: Being Addresses Delivered on Sunday Evenings to the Students of Tuskegee Institute, Doubleday Page and Company, New York 1903, 91. https://books.google.com/books?id=1GEPAAAAIAAJctprintsec=frontcover\&source= gbs_atb\# $\mathrm{v}=$ onepagectquf=false [accessed on 7 February 2019].

35 B.T. Washington, Democracy and Education, Address to Institute of Arts and Sciences, Brooklyn, NY September 1896, 15. https://www.blackpast.org/african-american-history/ speeches-african-american-history/1896-booker-t-washington-democracy-and-education/ [accessed on 8 February 2019]. 
your heads with knowledge or skillfully train your hands, but unless it is based upon high upright character, upon a true heart, it will amount to nothing." 36 An upright character, for Washington, yields happiness. He believed that " $[\mathrm{t}]$ he happiest people are those who do the most for others. The most miserable are those who do the least." ${ }^{37}$ An upright character, moreover, knows the value of self-reliance, of being able for instance to achieve one's goals without depending on government. He cautioned that, "[a]mong a large class, there seemed to be a dependence upon the Government for every conceivable thing. The members of this class had little ambition to create a position for themselves, but wanted the Federal officials to create one for them."38

Consistent with realism, Washington's leadership and activism were not egocentric. He recognized that "[e]gotism is the anesthetic that dulls the pain of stupidity." 39 He exposed idealistic leaders by observing that: "Most leaders spend time trying to get others to think

36 B.T. Washington, Black-Belt Diamonds: Gems from the Speeches, Addresses, and Talks to Students, ed. by V.E. Matthews, Fortune and Scott Publishers, New York 1898, 47. https://babel.hathitrust.org/cgi/pt?id=uva.x004545858;view=1up;seq=72 [accessed on 5 February 2019].

37 B.T. Washington, Up from Slavery: An Autobiography, in: J.H. Franklin, Three Negro Classics, Avon Books, New York 1965, Chapter XIV, 152.

38 B.T. Washington, Up from Slavery, in: J.H. Franklin, Three Negro Classics, op. cit., Chapter V, 76.

39 This quote is widely attributed to Washington in almost all of the creditable Washington "quote" sites. See, for example: https://en.wikiquote.org/wiki/Talk:Egotism; https:// iperceptive.com/authors/booker_t_washington_quotes.html; https://www.goodreads.com/quotes/168477-egotism-is-the-anesthetic-that-dulls-the-pain-of-stupidity [all accessed on 10 February 2019]. The quote, which has been cited for many years, could be from one of Washington's unpublished informal addresses, letters or student lectures. The credibility of its attribution to Washington is supported by the fact that its meaning conforms with Washington's consistent rejection of egotism. As he stated in various contexts, he valued a "life of unselfishness" (B.T. Washington, Up from Slavery, in: J.H. Franklin, Three Negro Classics, op. cit., Chapter XI, 117) and service to others, because "[i]n order to be successful in any kind of undertaking, I think the main thing is to grow to the point where [one] completely forgets [oneself]; that is to lose [oneself] in a great cause" (Ibidem, Chapter XII, 126). 
more highly of them, when instead they should try to get their people to think more highly of themselves. It's wonderful when people believe in their leaders. It's more wonderful when the leaders believe in their people!"40

Leaders should be oriented to their followers, not their own egos, for '[i]f you want to lift yourself up, lift up someone else.'41 Leaders should also realize that abstract visionary ideas and rhetorical arguments will not yield worthwhile outcomes simply because they are conceived by their own ego. In true realist fashion, Washington bluntly states that "we must reinforce argument with results." 42

With his humble character and his realism, Washington never allowed himself to vilify the Progressive intellectuals who maligned him. He was steadfast in his ethical principle that "I would permit no man, no matter what his color might be, to narrow and degrade my soul by making me hate him." ${ }^{43} \mathrm{He}$ had an abiding hope that AfricanAmericans will, through their own virtue and work, effect positive change in spite of the obstacles and challenges they have to face. "My experience is that the people who, call themselves 'The Intellectuals'

40 This quote is frequently attributed to Washington in many Washington "quote" sites. See, for example: AZQuotes.com, Wind and Fly LTD, 2019. https://www.azquotes.com/ quote/844250 [accessed on 02 February 2019]; https://www.usfca.edu/management/ news/booker-t-washington-and-guiding-the-public-administration-program [accessed on 02 February 2019]. The legitimacy of its attribution to Washington is supported by the fact that its meaning is consistent with Washington's denunciation of egotistic leadership and his belief in charity. He expressed these ideas in his statement that "great men cultivate love, and only little men cherish a spirit of hatred (...) assistance given to the weak makes the one who gives it strong (...) and oppression of the unfortunate makes one weak." (Ibidem, Chapter XI, 117).

41 cf. Ibidem, Chapter VI, 81.

42 B.T. Washington, The Educational and Industrial Emancipation of the Negro, An Address before the Brooklyn Institute of Arts and Sciences, Brooklyn, NY February 22, 1903, 25. http://teachingamericanhistory.org/library/document/the-educational-and-industrial-emancipation-of-the-negro/ [accessed on 10 February 2019].

43 B.T. Washington, Up from Slavery, in: J.H. Franklin, Three Negro Classics, op. cit., Chapter $\mathrm{XI}, 117$. 
understand theories, but they do not understand things. I have long been convinced that, if these men had gone into the South and taken up and become interested in some practical work which would have brought them in touch with people and things, the whole world would have looked very different to them. Bad as conditions might have seemed at first, when they saw that actual progress was being made, they would have taken a more hopeful view of the situation." 44

\section{CONCLUDING REMARKS: QUO VADIS LEADERSHIP?}

There is, at present, an abundance of leadership theories being taught in schools and practiced in organizations. Such theories range from servant leadership to transactional and transformational leadership to situational leadership. ${ }^{45}$ None of these theories explicitly advances a leadership elitism, per se, since to proclaim superiority, innate or otherwise, as a necessary condition for successful leaders would not be well received with today's emphasis on equality in organizations. There are, nevertheless, strong idealist tendencies in most of these theories, and one can justifiably claim that in today's teaching and practice of leadership, idealism dominates realism. Elitism, moreover, does persist, even though it is subtler than in the theories discussed above.

One of the main reasons for the persistence of idealist elitism today is the way in which hope and change are being addressed. In a widely read work on twenty-first century leadership, Lynn McFarland and others suggest "New Definitions for Leadership in the Twenty-First Century." A key definition proposed concerns the leader as a "change master." The authors argue that in today's organizations "[w]e have

44 B.T. Washington, My Larger Education, Doubleday, Page \& Co., Garden City, New York 1911 (electronic edition: Univ. of North Carolina, Chapel Hill), 12. https://docsouth.unc. edu/fpn/washeducation/washing.html\#wash102 [accessed on 1 February 2019].

45 Current leadership theories, such as those found in: P.G. Northouse, The Leader's Companion and Leadership: Theory and Practice, (Sage Publications, Los Angeles, CA 2013), are numerous and diverse. 
moved from the evolutionary changes that past leaders had to face to more revolutionary changes." ${ }^{6}$ Leaders as change masters must go beyond "merely reacting to change as it comes up, [... and start] predicting and redirecting change before it comes up." ${ }^{47}$ To be sure, fast-paced technological advancements, digital communication, and the almost taken-for-granted global scale of organizations have already made rapid change a reality. But what exactly are change-master leaders who can guide their organizations through the disruptions of change and yet retain a motivated, committed organization that can build for the future? 48

Such leaders, it would seem, would have to be a combination of some sort of seer and a charismatic dispenser of hope. They would have to be revolutionary leaders, constantly reinventing themselves and their organizations. Their visionary leadership and they themselves would have to be the origin and object of hope for an organization, for this would allow them to constantly rebuild its future.

Wouldn't such leaders then be some sort of superior and thereby elite "Ubermenschen" or "Ablemen," the masters of hope and change? In the political realm, moreover, couldn't such leaders engender a despotic totalitarianism wherein the followers, the people, are 'collectivized,' or even 'tribalized,' with assigned group identities according to the leader's visionary polis? Elitist idealist leadership evolving into political extremism truly poses a threat to human freedom. Given the preponderance of leadership idealism, where leadership is headed in the twenty-first century remains disturbingly uncertain.

46 L.J. McFarland, L.E. Senn, J.R. Childress, Redefining Leadership for the Next Century, in: The Leader's Companion, op. cit., 462. From: Twenty-First Century Leadership: Dialogues with 100 Top Leaders, ed. by L.J. McFarland, L.E. Senn, J.R. Childress, The Leadership Press, Inc., Long Beach, CA 1993, Chapter 6: Redefining Leadership for the Twenty-First Century.

47 Ibidem, 458-459.

48 Ibidem, 462. 


\section{APPENDIX: LEADERSHIP ELITISM - IDEALISM VS. REALISM}

\begin{tabular}{|c|c|}
\hline IDEALIST & REALIST \\
\hline $\begin{array}{l}\text { 1. Leadership is inherent or innate; } \\
\text { an inborn elitist superiority. }\end{array}$ & $\begin{array}{l}\text { 1. Leadership can be taught; leaders } \\
\text { can be formed through training and } \\
\text { education. }\end{array}$ \\
\hline 2. Leadership is a destiny fulfillment. & $\begin{array}{l}\text { 2. Leadership is earned by reaching } \\
\text { practical goals. }\end{array}$ \\
\hline 3. Utopian vision and ideals. & 3. Concrete, down-to-earth perspective. \\
\hline $\begin{array}{l}\text { 4. Leaders construct their own orga- } \\
\text { nizational reality. They aim to make } \\
\text { the organization conform to their own } \\
\text { vision. }\end{array}$ & $\begin{array}{l}\text { 4. Leaders lead within the given } \\
\text { parameters of the realities of an or- } \\
\text { ganization. They conform their goals } \\
\text { to the reality of an organization. }\end{array}$ \\
\hline $\begin{array}{l}\text { 5. Leaders invent their own standards or } \\
\text { principles, including ethical principles, } \\
\text { according to what they believe is best for } \\
\text { a situation. }\end{array}$ & $\begin{array}{l}\text { 5. Leaders discover the best and right } \\
\text { standards, principles and ethics through } \\
\text { conscientious learning, conform to them } \\
\text { and apply them to situations. }\end{array}$ \\
\hline $\begin{array}{l}\text { 6. Self-centered; egotistical; intolerant } \\
\text { of opposition. }\end{array}$ & 6. Other-oriented; humble; charitable. \\
\hline $\begin{array}{l}\text { 7. Hope and change: Hope is striving for } \\
\text { the "utopian" vision of reality the leader } \\
\text { defines (invents). Change is striving } \\
\text { to transform reality through any means, } \\
\text { to make reality conform to what the lea- } \\
\text { der hopes for. }\end{array}$ & $\begin{array}{l}\text { 7. Hope and change: Hope is respecting } \\
\text { what is discovered about reality and } \\
\text { trusting that conforming to the best } \\
\text { and right standards will lead to what is } \\
\text { good and successful. Change is striving } \\
\text { to actualize the best and right standards } \\
\text { within reality. }\end{array}$ \\
\hline $\begin{array}{l}\text { 8. The real consequences of the leaders' } \\
\text { ideas are ignored or de-emphasized. }\end{array}$ & $\begin{array}{l}\text { 8. Ideas have real consequences that } \\
\text { must be foreseen to the best of one's } \\
\text { ability and factored into assessments } \\
\text { of the ideas. }\end{array}$ \\
\hline $\begin{array}{l}\text { 9. Leaders view and treat followers (sub- } \\
\text { ordinates) as a collective entity having } \\
\text { a group identity based, for instance, on } \\
\text { race, ethnicity, gender, job position or } \\
\text { socio-economic status. }\end{array}$ & $\begin{array}{l}\text { 9. Leaders strive to respect and treat } \\
\text { followers as individual persons wit- } \\
\text { hout subsuming them into a collective } \\
\text { identity. }\end{array}$ \\
\hline
\end{tabular}




\section{REFERENCES}

Aristotle, Politics (excerpt), in: The Leader's Companion, ed. by J. Th. Wren, The Free Press, New York 1995.

Aristotle, Politics: A Treatise on Government, translated by W. Ellis, ed. by E. Rhys, J.M. Dent \& Sons, London 1941.

Bennis W., The Artform of Leadership, in: The Leader's Companion, ed. by J.Th. Wren, Simon and Schuster Inc., New York 1995, 377-378.

Carlyle Th., On Heroes, Hero Worship, and the Heroic in History, Lecture VI, The Hero as King, Ginn and Co., New York 1902, 223-226; in: The Leader's Companion, ed. by J. Th. Wren, Simon and Schuster Inc., New York 1995, 53-54.

Du Bois W.E.B., Negroes and Birth Control, in: The Birth Control Review, ed. by M. Sanger, April 1939 (reprint), Smith Libraries Exhibits, https://libex.smith. edu/omeka/items /show/491.

Du Bois W.E.B., On Stalin, National Guardian (1953) March 16, http://www. hartford-hwp.com/archives/45a/700.html.

Du Bois W.E.B., The Talented Tenth, in: The Negro Problem, James Pott \& Co., New York1903, 30-75, https://archive.org/stream/negroproblemseri00washrich/negroproblemseri00washrich_djvu; in: The Leader's Companion, ed. by J.Th. Wren, Simon and Schuster Inc., New York 1995, 75-80.

King M.L., Speech Honoring Dr. DuBois, New York City, Carnegie Hall, February 23, 1968, http://www.ushistory.org/documents/dubois.htm.

Lao Tzu, Tao Te Ching, in: The Tao of Leadership, ed. by J. Heider, Humanics Limited, Atlanta 1983, 1-163; Chapters 7, 10, 17, in: The Leader's Companion, ed. by J. Th. Wren, Simon and Schuster Inc., New York 1995, 69-71.

MacFarland L.J., Larry S., Childress J., Redefining Leadership for the Next Century, Chapter 6, in: Twenty-First Century Leadership: Dialogues with 100 Top Leaders, ed. by L.J. Macfarland, L. Senn, J. Childress, The Leadership Press, Inc., Long Beach, CA 2013; in: The Leader's Companion, ed. by J. Th. Wren, Simon and Schuster Inc., New York 1995, 456-463.

Machiavelli N., The Prince, Chapter XVII: How Princes Should Keep Faith, Limited Editions, New York 1954; in: The Leader's Companion, ed. by J. Th. Wren, Simon and Schuster Inc., New York 1995, 67-68.

McGill R., W.E.B. Dubois, The Atlantic Monthly (1965) November, https://www. theatlantic.com/past/docs/unbound/flashbks/black/mcgillbh.htm.

Moses W.T., Culture, Civilization and the Decline of the West, in: W.E. B. DuBois on Race and Culture, ed. by B. Bell, E. Gosholz, J. Stewart, Routledge, NewYork 2013, 243-260. 
Nevin F., The Contributions of Booker T. Washington and W.E.B. DuBois in the Development of Vocational Education, Journal of Industrial Teacher Education 34(1997), 87-91.

Northouse P., Leadership: Theory and Practice, Sage Publications, Long Beach, CA 2013.

Plato, The Republic of Plato, translated by Benjamin Jowett, Colonial Press, New York 1901; excerpt in: The Leader's Companion, ed. by J. Th. Wren, Simon and Schuster Inc., New York 1995, 60-64.

The Leader's Companion, ed. by J. Th. Wren, The Free Press, New York 1995.

The Wisdom of W.E.B. DuBois, ed. by Aberjhani, Kensington Publishing Corp., New York 2003.

Three Negro Classics, ed. by J.H. Franklin, Avon Books, New York 1965.

Tolstoy L., War and Peace, Book Three, Part One, translated by L. and A. Maude, Oxford University Press, New York 1903; Rulers and Generals Are 'History's Slaves, in: The Leader's Companion, ed. by J. Th. Wren, Simon and Schuster Inc., New York 1995, 55-59.

Washington B.T., Black-Belt Diamonds: Gems from the Speeches, Addresses and Talks to Students, ed. by V.E. Matthews, Fortune and Scott Publishers, New York 1898, https://babel.hathitrust.org/cgi/pt?id=uva.x004545858;view=1up;seq=72.

Washington B.T., Character Building, Doubleday, Page \& Co., New York 1903, https://books.google.com/books?id=1GEPAAAAIAAJ\&printsec=frontcove $\mathrm{r} \&$ source $=\mathrm{gbs} \_\mathrm{atb} \# \mathrm{v}=$ onepage $\& \mathrm{q} \& \mathrm{f}=$ false.

Washington B.T., Democracy and Education, Address to the Institute of Arts and Sciences, Brooklyn, NY 1896, https://www.blackpast.org/african-american-history/speeches-african-american-history/1896-booker-t-washington-democracy-and-education/.

Washington B.T., My Larger Education, Doubleday, Page \& Co., New York 1911. Electronic edition: Univ. of North Carolina, Chapel Hill. http://teachingamericanhistory.org/library/document/the-educational -and-industrial-emancipation-of-the-negro/.

Washington B.T., The Educational and Industrial Emancipation of the Negro, Address to the Brooklyn Institute of Arts and Sciences, Brooklyn, NY, February 22, 1903. http://teachingamericanhistory.org/library/document/ the-educational-and-industrial-emancipation-of-the-negro/.

Washington B.T., Up from Slavery, in: Three Negro Classics, ed. by J.H. Franklin, Avon Books, New York 1965, 25-205.

Webster's New Collegiate Dictionary, G. \& C. Merriam Co., Springfield, MA 1980. 
THOMAS A. MichaUd

tmichaud@westliberty.edu

West Liberty University, School of Professional Studies

Highlands Center, 355 Wharton Circle, WV 26059 Triadelphia, USA

DOI: $10.21697 /$ spch.2019.55.3.04 